\title{
Exoskeletal lesions in the male snow crab Chionoecetes opilio (Brachyura: Majidae) in the southern Gulf of St. Lawrence
}

\author{
Khadra Benhalima, Mikio Moriyasu, Elmer Wade, and Marcel Hébert
}

\begin{abstract}
During population surveys of the snow crab, Chionoecetes opilio, conducted in the southern Gulf of St. Lawrence, the prevalence of males with multiple exoskeletal lesions was recorded. Histological, histopathological, and scanning electron microscope observations revealed that the progressive lesions of the chitinous exoskeleton, usually accompanied by blackening of the necrotic region, were caused by Gram-positive bacilli. Between 1993 and 1995, an average of $2.1 \%$ of males larger than $60 \mathrm{~mm}$ carapace width $(\mathrm{CW})$ in the southern Gulf of St. Lawrence were infected by bacteria. Infected animals were found to be concentrated in an area with a high density of male crabs in the southern Gulf of St. Lawrence. Adolescent males of $<60 \mathrm{~mm} \mathrm{CW}$ bore a heavily infected exoskeleton less frequently than adult males, and no significant difference in the rate of molting failure was observed between infected and uninfected groups of adolescent males. There is no evidence that the incidence of bacterial lesions is increasing in the southern Gulf of St. Lawrence.

Résumé : Les relevés au chalut de la population du crabe des neiges (Chionoecetes opilio) dans le sud du golfe du Saint-Laurent ont mis en lumière la présence de lésions multiples sur la carapace des animaux. Les observations histologiques et histopathologiques et l'examen au microscope à balayage ont révélé que ces lésions progressives de la partie chitineuse de l'exosquelette étaient causées par des bactéries Gram positif et qu'il y avait noircissement des zones nécrosées. Entre 1993 et 1995, en moyenne de 2,1\% des mâles de taille supérieure à $60 \mathrm{~mm}$ (largeur de la carapace, LC) dans le sud du golfe du Saint-Laurent étaient infectés. Les animaux infectés étaient concentrés surtout dans les régions du golfe où la population de mâles était très dense. Les mâles adolescents de taille supérieure de $60 \mathrm{~mm}$ (LC) portaient moins de lésions graves que les adultes et aucune différence significative du taux de mortalité lors de la mue n'a été enregistrée entre les mâles adolescents infectés et sains. Rien ne nous permet de croire que la fréquence des infections bactériennes de l'exosquelette soit à la hausse dans le sud du golfe du Saint-Laurent.
\end{abstract}

\section{Introduction}

The snow crab Chionoecetes opilio is the most important commercially exploited crab species in eastern Canada. Recently this species has been exported mainly as frozen cooked or raw products with shell to Japan. The snow crab industry has reported a high prevalence of shell disease in commercial-size males ( $\geq 95 \mathrm{~mm}$ carapace width (CW)) in 1992, which could significantly lower the commercial value.

In natural populations, shell disease is frequently reported in various species of commercially important crustaceans, including brachyuran crabs: the blue crab, Callinectes sapidus (Rosen 1967, 1970; Overstreet and Cook 1972; Cook and Lofton 1973; Sandifer and Eldridge 1974; Iversen and Beardsley 1976); Dungeness crab, Cancer magister (Baross et al. 1978); shore crab, C. pagurus (Gordon 1966; Bakke 1973; Leglise 1976; Ayre and Edwards 1982); rock crab, C. irroratus (Sawyer 1982); Jonah crab, C. borealis (Haefner 1977); stone crab, Menippe mercenaria (Iversen and Beardsley 1976); red crab, Chaceon quinquedens (Bullis et al. 1988); and golden

Received August 18, 1997. Accepted November 18, 1997.

K. Benhalima, M. Moriyasu, ${ }^{1}$ E. Wade, and M. Hébert. Department of Fisheries and Oceans, Maritime Region, Science Branch, Gulf Fisheries Center, P.O. Box 5030, Moncton, NB E1C 9B6, Canada.

Author to whom all correspondence should be addressed (e-mail: moriyasum@mar.dfo-mpo.gc.ca). crab, C. fenneri (Wenner et al. 1987). Although mortality of adult crabs attributed directly to shell disease is believed to be infrequent (Rosen 1970; Fisher et al. 1978), this phenomenon, if widespread, can affect the commercial value of exploited species (Edwards 1979). In addition, some authors have used measures of exoskeletal erosion and blackened gills as indicators of pollution (Sawyer et al. 1983; Young and Pearse 1975).

In the genus Chionoecetes, two types of shell disease are reported from the eastern Pacific: (1) "black mat syndrome" caused by the ascomycete fungus Trichomaris invadens (van Hyning and Scarborough 1973; Sparks and Hibbits 1979; Hibbits et al. 1981; Sparks 1982) and (2) "black spot" ("brown spot," "rust spot," or "burn spot") caused by chitinolytic bacteria, mainly Vibrio spp. and Pseudomonas spp., but also luminescent Photobacterium spp. and Maraxella spp. (Baross et al. 1978). However, little information is available on shell disease in the snow crab in eastern Canada (Bower et al. 1994). This paper reports the prevalence of shell disease in male snow crabs over a 3-year period in the southern Gulf of St. Lawrence, and the results of microscopic and microbiological analyses of the exoskeletal lesions.

\section{Materials and methods}

Sample collection

A large-scale trawl survey has been conducted in the southern Gulf of St. Lawrence since 1989, and the prevalence of shell disease in male crabs was noted during the 1993-1995 surveys. The following measurements were collected from all crabs caught: carapace width 
Fig. 1. Macroscopic and histological details of the exoskeleton of a snow crab (Chionoecetes opilio) infected by chitinolytic bacteria. (A) Early stage of infection, showing lesions on the exoskeleton as small brown circles with a white center $(\rightarrow)$. (B) Intermediate stage of infection, showing darkened spots $(\rightarrow)$. (C) Late stage of infection, showing the eroded and blackened center $(\rightarrow)$. (D) Light photomicrograph of a transverse section of the cuticle at the early stage of infection, showing the very thin epicuticular layer with perforations. (E) Light photomicrograph of a transverse section of the cuticle at the intermediate stage of infection; the epicuticular and exocuticular layers are damaged by the infection and the epithelial layer appears to be invaginated $(\rightarrow)$ ). (F) Light photomicrograph of a transverse section of the cuticle at the late stage of infection, showing severely blackened tissues. All cuticular layers are congested with infected tissue. A wide space separates the cuticle from the underlying epithelium $(\leftrightarrow)$ containing dense material and droplets. En, endocuticle; Ep, epicuticle; Epi, epithelium; Ex, exocuticle; Inf, infection; L, lesion; ML, membranous layer; Ct, connective tissue.

Table 1. Criteria for determining shell disease stages in the snow crab Chionoecetes opilio in the southern Gulf of St. Lawrence.

\begin{tabular}{|c|c|c|}
\hline Stage & $\begin{array}{l}\text { Degree of } \\
\text { infection }\end{array}$ & Criteria \\
\hline Uninfected & Imperceptible & No visible spots \\
\hline I & Slight & Small light patches \\
\hline II & Moderate & $\begin{array}{l}\text { Small patches forming a } \\
\text { crater a with a blackened center }\end{array}$ \\
\hline III & Severe & $\begin{array}{l}\text { Blackening necrosis present, infected } \\
\text { areas cracked and (or) softened }\end{array}$ \\
\hline
\end{tabular}

(CW, $\mathrm{mm})$, chela height $(\mathrm{CH}, \mathrm{mm})$, carapace rigidity, measured with a durometer (Foyle et al. 1989), carapace condition and the degree of infection (uninfected or slightly, moderately, or severely infected; Table 1). The terminology used for the maturity status of male crabs follows Sainte-Marie et al. (1995). Contingency table analysis was conducted to compare the rates of infection between adolescent and adult males in the same year. Effects were deemed significant at the $P<0.05$ level. To elucidate the geographic distribution of infected animals larger than $60 \mathrm{~mm} \mathrm{CW}$ in the southern Gulf of St. Lawrence, the data were compiled and analyzed by a geostatistical technique, kriging (Matheron 1970; Clarke 1979; Conan 1985; Moriyasu et al. 1998).

Male snow crabs were collected between July and October 1994 using a Bay of Biscay "Bigouden" Nephrops otter trawl (Conan et al. 1994 ) in the southern Gulf of St. Lawrence at depths ranging from 50 to $100 \mathrm{~m}$. In total, 4005 male crabs ranging from 60 to $134 \mathrm{~mm} \mathrm{CW}$ were obtained. Five specimens per degree of infection (a total of 20) were brought to the laboratory for histological, histopathological, and scanning electron microscope (SEM) observations.

\section{Molting observations}

During the molting season of adolescent males, between January and April, the rate of molting failure was observed in 79 infected adolescent males (61-125 mm CW) and 122 uninfected adolescent males $(58-127 \mathrm{~mm} \mathrm{CW})$. Each premolt adolescent male was placed in a $60 \times 60 \times 45 \mathrm{~cm}$ compartment until the old carapace was completely shed. Natural seawater was continuously pumped from Baie des Chaleurs into the reservoir tank and then passed through a sand-filter tank, charcoal filter, and ultraviolet sterilizer before distribution to each aquarium. During the observation period, the water temperature varied between 0 and $3^{\circ} \mathrm{C}$ and salinity between 28.5 and $30 \mathrm{ppm}$. Crabs were fed smelt (Osmerus mordax) and pink shrimp (Pandalus borealis) twice a week. Crabs were kept in dim light and all observations were made under red light to minimize disturbance of molting activity. If an individual died during the process of molting, this was considered molting failure. Contingency analysis was conducted to compare the rates of molting failure between infected and uninfected groups. Effects were deemed significant at the $P<0.05$ level.

Histological and histopathological observations

For light microscopy observations, an approximately $1 \mathrm{~cm}^{2}$ section of infected exoskeleton were excised using sterile techniques and preserved in Bouin's fixative solution for $48 \mathrm{~h}$. Fixed tissue was dehydrated in a series of graded ethanol solutions (50, 70, 95, and 100\%), cleared in xylene, then embedded using a paraffin wax vacuum chamber. The cuticle samples were not decalcified, therefore a longer embedding time (12-24 h) was required to allow complete penetration of paraffin wax into the sample tissue. Serial sections ( $5 \mu \mathrm{m}$ thick) were mounted on glass slides and stained with modified Masson's trichrome, a modification of Goldener (Martoja and Martoja-Pierson 1967), then dehydrated with ethanol and cleared with xylene. For microbiological studies, Gram's stain was applied to fresh smears of the necrotic areas.

\section{SEM observations}

SEM observations were made on infected samples of exoskeleton excised from the animals by means of sterile techniques. Small pieces $\left(1 \mathrm{~cm}^{2}\right)$ were fixed for $1 \mathrm{~h}$ at $4{ }^{\circ} \mathrm{C}$ in $5 \%$ cold glutaraldehyde (with $0.1 \mathrm{M}$ cacodylate buffer at $\mathrm{pH} 7.2$ ) and rinsed in cold $0.175 \mathrm{M}$ cacodylate buffer at $\mathrm{pH}$ 7.2. Specimens were postfixed with $2 \%$ osmium tetroxide in $0.31 \mathrm{M}$ cacodylate buffer at $\mathrm{pH} 7.2$ for $1 \mathrm{~h}$, then rinsed in the buffer described above. Following dehydration $(10 \mathrm{~min})$ through a graded ethanol series, the specimens were placed in a Polaron CPD750 critical-point dryer and infiltrated with liquid carbon dioxide for $1 \mathrm{~h}$ before being dried by passing through the critical point. The sections were mounted on scanning electron microscope stubs using silver paint as an adhesive. The stubs were coated under vacuum with a 10-15 nm thick layer of gold-palladium. The samples were viewed with a Model JEOL 1500 SEM at $15 \mathrm{kV}$ acceleration voltage.

\section{Results}

\section{Histological observations}

In general, multiple lesions of the exoskeleton were most frequently located on the walking appendages. As the infection progressed, severe burn spots appeared on the exoskeleton, resulting in extensive damage to the infected areas. The infected areas were soft and easily broken.

In macroscopic and microscopic observations, the early stage of the infection (stage I; Table 1) was recognized as numerous punctiform necrotic spots (light brown) on the surface of the exoskeleton (Fig. 1A). The necrotic areas stained very densely with Masson's trichrome and showed penetration of bacteria through the thin epicuticular layer (Fig. 1D). At the beginning of the infection, the epicuticle, usually smooth and continuous, was affected by a small perforation, and the center of the spots became friable (Fig. 1D). At the moderateinfection stage (stage II; Table 1), brownish necrotic lesions with a circular depressed center (red) were observed on the exoskeleton (Fig. 1B). The degradation progressed slowly through each cuticular layer, resulting in a dense necrotic lesion (Fig. 1E). The columnar epithelial cells below the infected cuticle became eroded and formed a depression 





Fig. 2. SEM observations of the exoskeleton of a snow crab (Chionoecetes opilio) infected by chitinolytic bacteria. (A) Scanning electron micrograph of the cuticular surface of a walking leg covered with debris and a cuticular lesion (stage I). (B) Scanning electron micrograph revealing the centrally aggregated crater of the cuticular lesion (stage II). (C) Scanning electron micrograph showing the crater of the cuticular lesion (stage III). (D) Scanning electron micrograph of the cuticular lesion, showing a morphologically homogeneous population of bacteria. (E) Scanning electron micrograph showing the vertical distribution of the bacterial colony around the crater area. (F) Scanning electron micrograph of the cuticular lesion, showing bacterial encrustation. B, bacteria; CL, cuticular lesions; Cr, crater; D, debris.

Table 2. Numbers of samples and lightly infected (stages I and II) and severlly infected (stage III) male snow crabs (Chionoecetes opilio) observed during bottom-trawl surveys from 1993 to 1995 in the southern Gulf of St. Lawrence.

\begin{tabular}{llll}
\hline & 1993 & 1994 & 1995 \\
\hline Adolescents & & & \\
$\quad$ Lightly infected & 90 & 33 & 11 \\
Severely infected & 17 & 5 & 1 \\
Uninfected & 3638 & 4196 & 2894 \\
$\quad$ Total no. examined & 3745 & 4234 & 2906 \\
Adults & & & \\
Lightly infected & 170 & 65 & 34 \\
Severely infected & 39 & 14 & 11 \\
Uninfected & 4488 & 4805 & 3270 \\
Total no. examined & 4697 & 4884 & 3315 \\
\hline
\end{tabular}

Note: For an explanation of stages see Table 1.

(Fig. 1E). At the advanced-lesion stage (stage III; Table 1), the surface of the infected area became a deep, black necrotic area with an irregular profile (Fig. 1C). In advanced infections, there was progressive degeneration of the epithelium (Fig. 1F) until it was completely disrupted. Below the epithelium, the connective tissue was fibrillar and spongy with numerous blood cells (Fig. 1F). In the terminal stage of infection, all cuticular layers were infected by proliferating bacteria. A wide space was observed between the cuticular layers and the underlying epithelium, which contained accumulated debris and droplets (Fig. 1F). The subdermal space became progressively wider as the infection progressed. In contrast, all layers of the uninfected zone of the cuticle (epi-, exo-, and endo-cuticle and membranous layer) were discernible and intact. The bacteria seen in the fresh smear from the necrotic area were Grampositive (stained deep blue) and rod-shaped.

\section{SEM observations}

The lesions examined by SEM showed distinguishable infected areas with a regularly cracked exoskeleton (Fig. 2A). At the moderate-infection stage, infected areas become circular, with a crater-like pit in the center (Fig. 2B). Severe lesions showed erosion of the infected area (Figs. 2C, 2E). At high magnification, these areas were seen to be coated with colonies of rod-shaped bacteria, which were arranged vertically against the surface of the cuticle (Figs. 2E, 2F). The density of bacteria on the exoskeleton was high in the central area of the infection and decreased in the peripheral area (Fig. 2D).

\section{Geographic distribution and molting failure of infected males}

The average annual percentage of infected males larger than $60 \mathrm{~mm} \mathrm{CW}$ decreased from $3.7 \%$ in 1993 to $0.9 \%$ in 1995 . The prevalence of infection (Table 2) was significantly higher in adult males $(4.45 \%$ in $1993,1.62 \%$ in 1994 , and $1.36 \%$ in
$1995)$ than in adolescent males ( $2.86 \%$ in $1993,0.90 \%$ in 1994 , and $0.41 \%$ in 1995$)$ over the 3 -year survey period $(P<0.0025)$. The prevalence of severe infection (stage III) was significantly higher $(P<0.01)$ in adult males $(0.83 \%$ in 1993 and $0.33 \%$ in $1995)$ than in adolescent males $(0.45 \%$ in 1993 and $0.03 \%$ in 1995) in 1993 and 1995, but the difference was not significant $(P=0.0784)$ in 1994 (0.29 vs. $0.12 \%)$. The geographic distribution of infected males larger than $60 \mathrm{~mm} \mathrm{CW}$ was greater in the northwestern part of the study area (Fig. 3).

Molting of captive adolescent males seemed to be unaffected by the infections. Molting failure in the infected adolescent males (7 individuals out of 79 observations) was not significantly different $\left(\chi^{2}=0.003, \mathrm{df}=1, P=0.9557\right)$ from that in the uninfected group (11 individuals out of 122 observations) observed in captivity.

\section{Discussion}

Causative bacteria and infection

Five genera (Pseudomonas, Vibrio including Beneckea, Aeromonas, Spirillum, and Flavobacterium) of chitinolytic bacteria were reported in crustaceans with shell disease by Cook and Lofton (1973), Malloy (1978), and Lightner (1988). Hess (1937) reported shell disease in American lobsters caused by chitin-destroying Gram-negative bacilli similar to Bacillus chitinovorous Types II and XIV of Benton (1935). Baross et al. (1978) reported exoskeletal lesions in Tanner crabs (C. tanneri) caused by the luminous chitin-digesting bacteria Photobacterium sp., Maraxella spp., and a species similar to Vibrio anguillarum. Although the shell disease of snow crab reported here is caused by chitin-destroying Gram-positive bacilli, further identification of the species was not possible.

The uppermost layer, the epicuticle, is made up of lipoproteins rather than chitin, which offers some protection against chitin-destroying bacteria (Young 1989). However, physical damage to the epicuticle, such as that caused by the frequent discarding of soft-shelled crabs by commercial fishermen, may facilitate the entry of chitin-destroying bacteria into inner layers. Hess (1937), Sawyer and Taylor (1949), and Rosen (1967) reported that introduction of bacteria was unsuccessful if the epicuticle was left intact, therefore careful handling by fishers is suggested when returning undersized soft-shelled snow crabs to the sea, to reduce unnecessary cuticular damage. In addition, chitinolytic bacteria are most numerous in the topmost layers of mud (Zobell and Rittenberg 1938), therefore bottom-dwelling species that burrow into bottom sediment, such as the snow crab, are much more susceptible to infection by chitinolytic bacteria. Contrary to the observations of Hess (1937), the infection is not entirely external and can reach living tissues. However, this seems to occur only in terminalmolt crabs with old carapace corresponding to a carapace age of 5-6 years (Sainte-Marie and Dufour 1994). Mortality of snow crabs that was due directly to shell disease seemed to be 

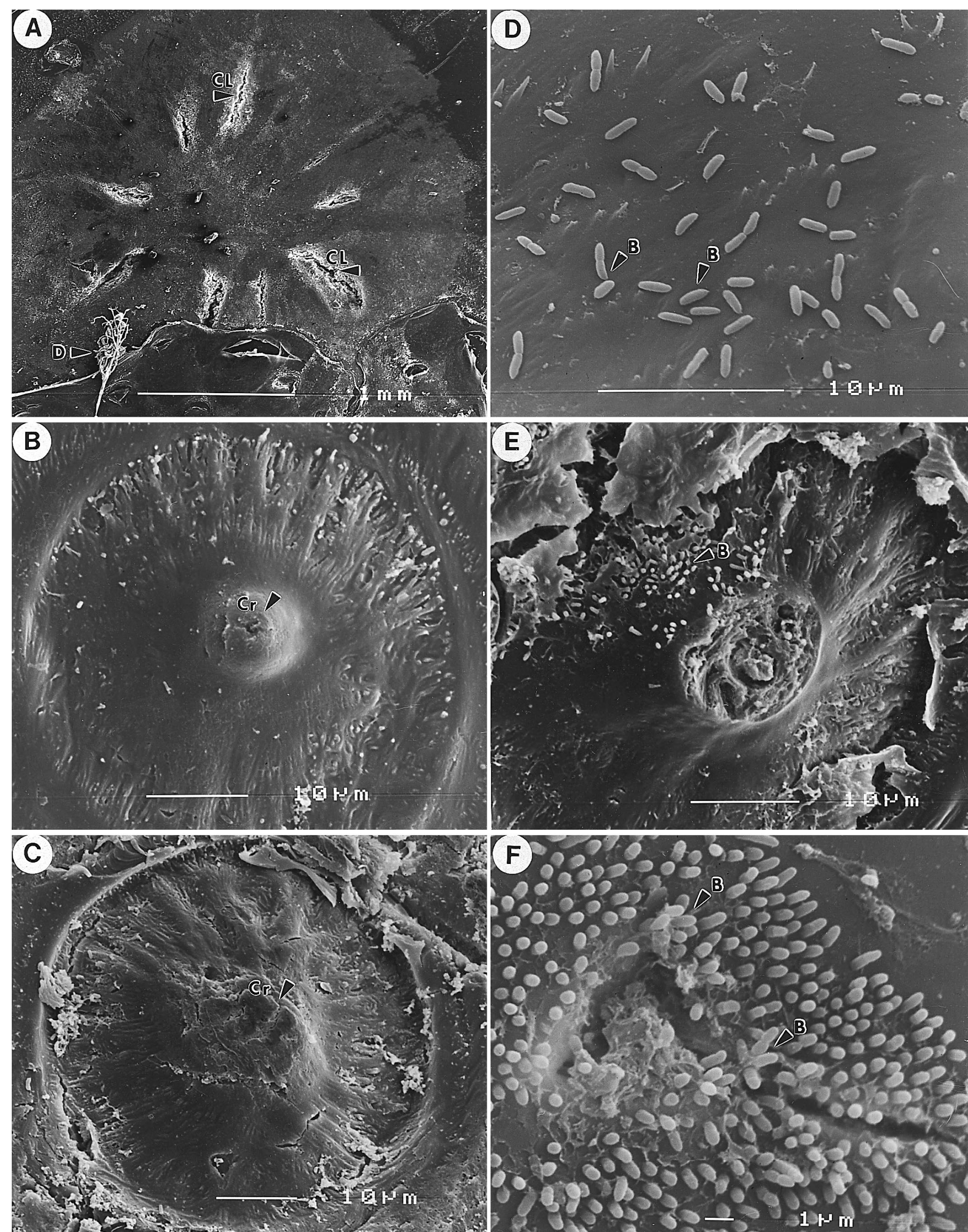

\section{(F)}

$\operatorname{lop}_{0} 3009$

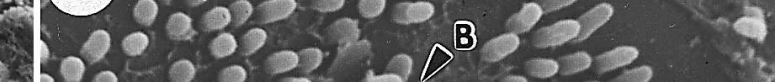
$100002-30302$

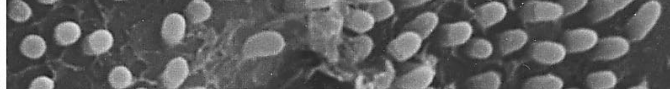
3

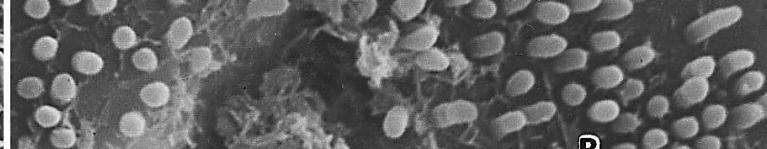

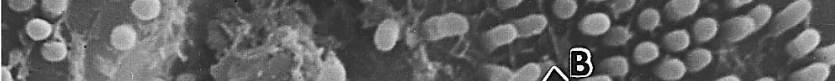

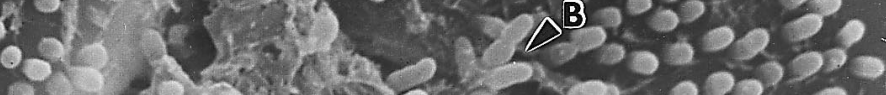
Q 3.

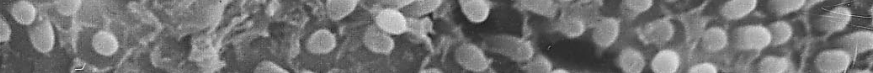

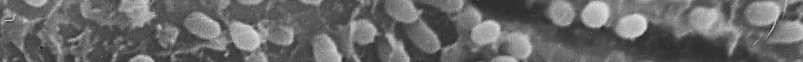

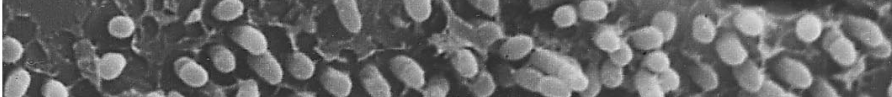

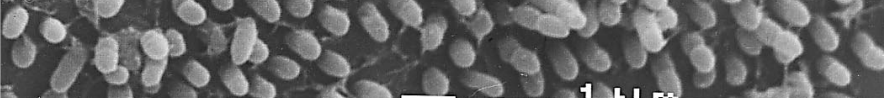


Fig. 3. Geographic distribution of population density contours of infected male snow crabs (Chionoecetes opilio) larger than $60 \mathrm{~mm} \mathrm{CW}$ in the southern Gulf of St. Lawrence between 1993 and 1995, calculated by means of kriging based on the bottom-trawl surveys.

\section{3}

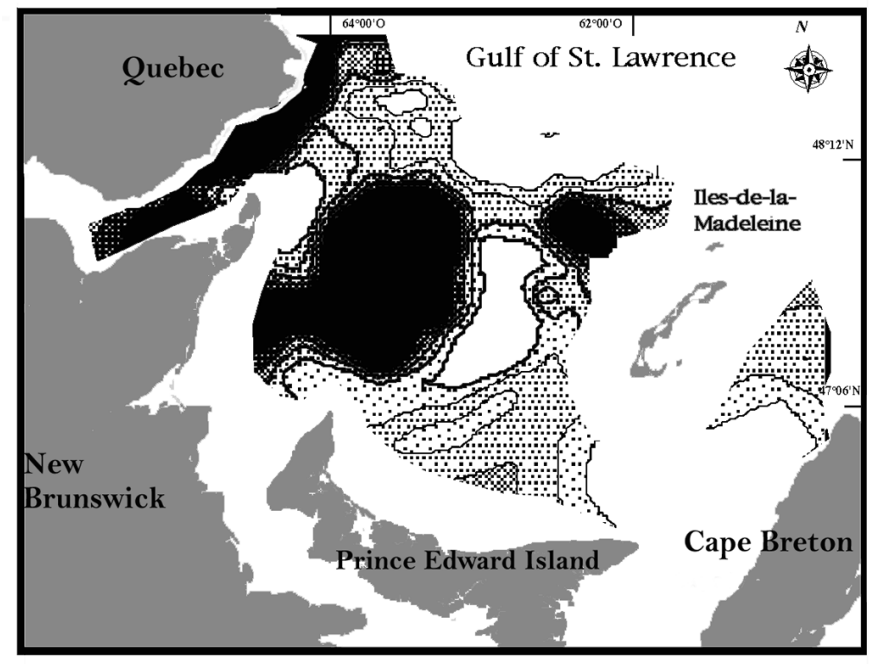

\section{4}

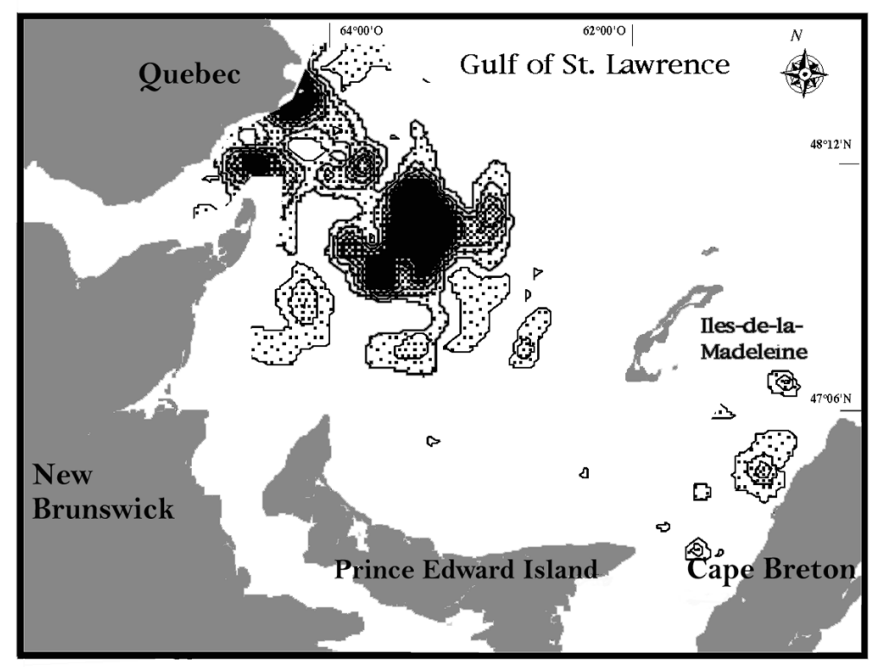

\section{5}

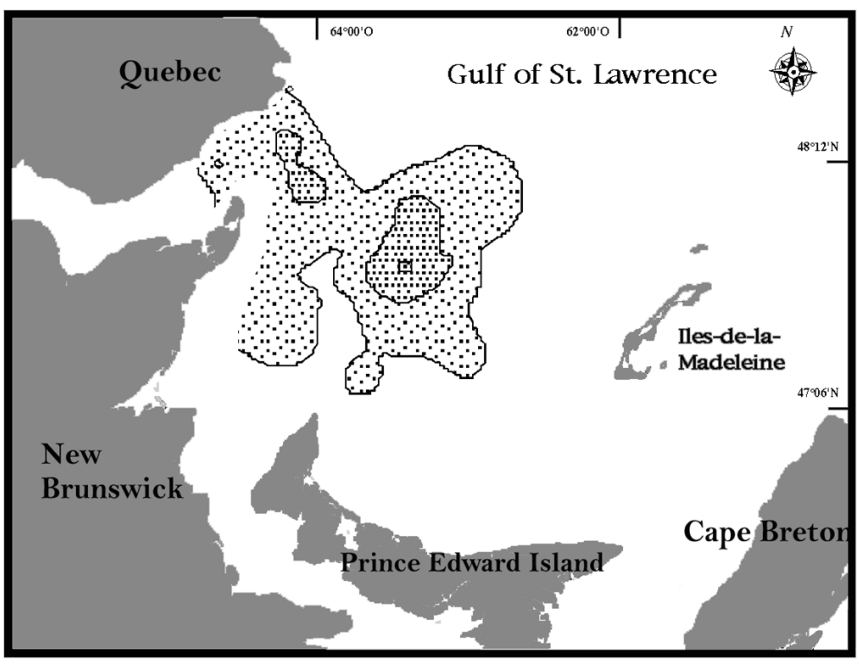

Number $/ \mathbf{k m}^{2}$

1000

800

600

400

200 
infrequent, especially since the prevalence of infection in the survey was low.

In snow crabs, chitin destruction seemed to be much slower, more than 1 year for severe chitin infection, than is observed in American lobsters (Sindermann and Rosenfield 1967). Juvenile and adolescent crabs usually molt at least once a year, thus they may be able to shed an infected carapace before the infection becomes invasive, as has been observed in other crustaceans (McLeese 1965; Rosen 1970). The majority of newly molted crabs were free of clinical signs of shell disease, as was reported for $C$. tanneri (Baross et al. 1978). Terminally molted snow crabs (adult), however, show a higher prevalence of the infection because they do not shed the infected carapace. The same phenomenon was reported by Young (1989) for the larger red crab, which has a longer intermolt period (probably longer than 1 year).

\section{Prevalence of infection and distribution of infected male snow crabs}

The average percentage $(2.1 \%)$ of infected males is much lower than that reported for red crabs, where it can be $86-92 \%$ (Young 1989). Baross et al. (1978) reported that the prevalence of infection in female Tanner crabs $(76 \%)$ was higher than in males $(29 \%)$.

The percentage of infected animals decreased between 1993 and 1995. Because the total abundance of adolescent and adult males in the southern Gulf of St. Lawrence has also been decreasing annually since 1993 (Anonymous 1997), the prevalence of infection may correspond to the density of male crabs in this area. High population densities may encourage the spread of these infections (McLeese and Wilder 1964; Rosen 1967), especially for species with an aggregate distribution, such as snow crabs. Adolescent males appeared not to be severely affected by the infection, whereas terminally molted males seemed to be susceptible to severe infection.

The decrease in the prevalence of infection between 1993 and 1995, parallel to the decrease in male crab abundance, leads to the suggestion that the temporary increase in shell disease in the southern Gulf of St. Lawrence was associated with high crab abundance. This phenomenon, therefore, is not a significant threat to the snow crab industry in this area.

\section{Acknowledgments}

The authors express their thanks to Drs. E.M.P. Chadwick, J.M. Hanson, and S. McGladdery (Department of Fisheries and Oceans, Moncton, N.B.) for their critical review of the manuscript. Thanks are also expressed to the representatives of the snow crab industry in the southern Gulf of St. Lawrence for valuable information on crab infection, Y. Chiasson (Department of Fisheries and Oceans, Moncton, N.B.) for sample collection, A. Hébert (Pèse-Pêche, Inc., Shippagan, N.B.) for data compilation, and Ms C.S. Belfry (Microscope Unit, University of New Brunswick, Fredericton) for her assistance with the preparation of scanning electron micrographs. Funding for this work came from the Atlantic Fisheries Adjustment Program of the Department of Fisheries and Oceans Canada.

\section{References}

Anonymous. 1997. Southern Gulf snow crab. DFO Science Stock
Status Rep. C3-01, Department of Fisheries and Oceans Canada, Dartmouth, N.S.

Ayre, P., and Edwards, E. 1982. Notes on the distribution of "black spot" shell disease in crustacean fisheries. Chem. Ecol. 1: 125-130.

Bakke, T.A. 1973. Brannflekk-syke hos taskekrabber, Cancer pagurus L., i Norge. Fauna, 26: 141-143.

Baross, J.A., Tester, P.A., and Morita, R.Y. 1978. Incidence, microscopy, and etiology of exoskeleton lesions in the tanner crab, Chionoecetes tanneri. J. Fish. Res. Board Can. 35: 1141-1149.

Benton, A.G. 1935. Chitinovorous bacteria: a preliminary survey. J. Bacteriol. 29: 449-463.

Bower, S.M., McGladdery, S.E., and Price, I.M. 1994. Synopsis of infectious diseases and parasites of commercially exploited shellfish. Annu. Rev. Fish Dis. 4: 1-199.

Bullis, R., Leibovitz, L., Swanson, L., and Young, R. 1988. Bacteriologic investigation of shell disease in deep sea red crab, Geryon quinquedens. Biol. Bull. (Woods Hole, Mass.), 175: 304.

Clark, I. 1979. Practical geostatistics. Elsevier Science Publications, London and New York.

Conan, G.Y. 1985. Assessment of shellfish stock by geostatistical techniques. Int. Counc. Explor. Sea C.M. 1985/K:30.

Conan, G.Y., Comeau, M., Gosset, C., Robichaud, G., and Garaïcoechea, C. 1994. The Bigouden Nephrops trawl, and the devismes trawl, two otter trawls efficiently catching benthic stages of snow crab (Chionoecetes opilio) and the American lobster (Homarus americanus). Can. Tech. Rep. Fish. Aquat. Sci. No. 1992.

Cook, D.W., and Lofton, S.R. 1973. Chitinoclastic bacteria associated with shell disease in Penaeus shrimp and the blue crab (Callinectes sapidus). J. Wildl. Dis. 9: 154-159.

Edwards, E. 1979. The edible crab and its fishery in British waters. Fishing News Books Ltd. Farnham, Surrey, England.

Fisher, W.S., Nilson, E.H., Steenbergen, J.F., and Lightner, D.V. 1978. Microbial diseases of cultured lobsters: a review. Aquaculture, 14: 115-140.

Foyle, T.P., Hurley, G.V., and Taylor, D.M. 1989. Field testing shell hardness gauges for the snow crab fishery. Can. Ind. Rep. Fish. Aquat. Sci. No. 193.

Gordon, I. 1966. Parasites and diseases of Crustacea. Mem. Inst. Fondam. Afr. Noire, 77: 27-86.

Haefner, P.A. 1977. Aspect of the biology of the Jonah crab, Cancer borealis Stimpson, 1859 in the mid-Atlantic Bight. J. Nat. Hist. 11: $303-320$

Hess, E. 1937. A shell disease in lobsters (Homarus americanus) caused by chitinovorous bacteria. J. Biol. Board Can. 3: 358-362.

Hibbits, J., Hughes, G.C., and Sparks, A.K. 1981. Trichomaris invadens gen. et sp.nov., an ascomycete parasite of the tanner crab (Chionoecetes bairdi Rathbun Crustacea; Brachyura). Can. J. Bot. 59: 2121-2128.

Iversen, E.S., and Beardsley, G.L. 1976. Shell disease in crustaceans indigenous to south Florida. Progr. Fish-Cult. 38: 195-196.

Leglise, M. 1976. Les maladies parasitaires et microbiennes des crustacés. Oceanis, 3: 176-189.

Lightner, D.V. 1988. Bacterial shell (brown spot) disease of penaeid shrimp. In Disease diagnosis and control in North American marine aquaculture. Edited by C.J. Sindermann and D.V. Lightner. Elsevier, New York. pp. 48-51.

Malloy, S.C. 1978. Bacteria induced shell disease of lobster (Homarus americanus). J. Wildl. Dis. 14: 2-10.

Martoja, R., and Martoja-Pierson, M. 1967. Initiation aux techniques de l'histologie animale. Masson et Cie, Paris.

Matheron, G. 1970. La théorie des variables régionalisées et ses applications. Les Cahiers du Centre de Morphologie Mathématique de Fontainebleau. Fasc. 5.

McLeese, D.W. 1965. Lesions on the abdominal membrane of lobsters. J. Fish. Res. Board Can. 22: 639-641.

McLeese, D.W., and Wilder, D.G. 1964. Lobster storage and shipment. Bull. Fish. Res. Board Can. No. 147. 
Moriyasu, M., Wade, E., Sinclair, A., and Chiasson, Y. 1998. Snow crab, Chionoecetes opilio, stock assessment in the southwestern Gulf of St. Lawrence by bottom trawl survey. Can. Spec. Publ. Fish. Aquat. Sci. No. 125. pp. 29-40.

Overstreet, R.M., and Cook, D.W. 1972. An underexploited Gulf coast fishery: soft shelled crabbing. Am. Fish Farmer, 3(9): 12-17.

Rosen, B. 1967. Shell disease of the blue crab, Callinectes sapidus. J. Invertebr. Pathol. 9: 348-353.

Rosen, B. 1970. Shell disease of aquatic crustaceans. Am. Fish. Soc. Spec. Publ. No. 5. pp. 409-415

Sainte-Marie, B., and Dufour, R. 1994. Crabe des neiges de l'estuaire et du nord du golfe Saint-Laurent (zones de pêche 13, 14, 15, 16 et 17). Saint-Laurent. Can. Manuscr. Rep. Fish. Aquat. Sci. No. 2257. pp. 2-23.

Sainte-Marie, B., Raymond, S., and Brêthes, J.-C. 1995. Growth and maturation of the benthic stages of male snow crab, Chionoecetes opilio (Brachyura: Majidae). Can. J. Fish. Aquat. Sci. 52: 903-924.

Sandifer, P.A., and Eldridge, P.J. 1974. Observations on the incidence of shell disease in South Carolina blue crabs, Callinectes sapidus. In Proceedings of Gulf Coast Regional Symposium on Diseases of Atlantic Animals, Baton Rouge, La., 16-17 August 1974. Edited by R.L. Amborski, M.A. Hood, and R.R. Miller. Publ. No. LSU-SG-74-05, Louisiana State University, Baton Rouge. pp. 161-184.

Sawyer, T.K. 1982. Distribution and seasonal incidence of "black gill" in the rock crab, Cancer irroratus. In Ecological stress and the New York Bight: science and management. Edited by F. Mayer. Estuarine Research Foundation, Columbia, S.C. pp. 199-211.

Sawyer, T.K., Lewis, E.J., Galasso, M., Bodammer, S., Ziskowski, J., Lear, D., O’Malley, M., and Smith, S. 1983. Black gill conditions in the rock crab, Cancer irroratus, as an indicator of ocean dump- ing in Atlantic coastal waters of the United States. Rapp. P.-V. Reun. Cons. Int. Explor. Mer, 182: 91-95.

Sawyer, W.H., Jr., and Taylor, C.C. 1949. The effect of shell disease on the gill and chitin of the lobster (Homarus americanus). Res. Bull. No. 1, Department of Sea and Shore Fisheries, Augusta, Maine. pp. 1-10.

Sindermann, C.J., and Rosenfield, A. 1967. Principal diseases of commercially important marine bivalve Mollusca and Crustacea. Fish. Bull. 66: 335-385.

Sparks, A.K. 1982. Observations on the histopathology and probable progression of the disease caused by Trichomaris invadens, an invasive ascomycete, in the Tanner crab, Chionoecetes bairdi. J. Invertebr. Pathol. 40: 242-254.

Sparks, A.K., and Hibbits, J. 1979. Black mat syndrome, an invasive mycotic disease of the Tanner crab, Chionoecetes bairdi. J. Fish Dis. 3: 285-293.

van Hyning, J.M., and Scarborough, A.M. 1973. Identification of fungal encrustation on the shell of the snow crab (Chionoecetes bairdi). J. Fish. Res. Board Can. 30: 1738-1739.

Wenner, E.L., Ulrich, G.F., and Wise, J.B. 1987. Exploration for golden crab, Geryon fenneri, in the South Atlantic Bight: distribution, population structure, and gear assessment. Fish. Bull. 85: $547-560$.

Young, J.S., and Pearse, J.B. 1975. Shell disease in crabs and lobsters from New York Bight. Mar. Pollut. Bull. 6: 101-105.

Young, R.R. 1989. Shell disease among red crabs inhabiting submarine canyons of the New York Bight. NOAA Tech. Mem. NMFS-F/NEC-77.

Zobell, C.E., and Rittenberg, S.C. 1938. The occurrence and characteristics of chitinoclastic bacteria in the sea. J. Bacteriol. 35: 275-287. 